\title{
Assessment of Activity Concentration of Radionuclides in Sediment from Oil Producing Communities of Delta State, Nigeria
}

\author{
Caroline Nihinlola Iwetan ${ }^{1 *}$, Ibiyinka Agboola Fuwape ${ }^{1}$, Adeseye Muyiwa Arogunjo1, \\ Ganiyu Obor ${ }^{2}$ \\ ${ }^{1}$ Physics Department, Federal University of Technology, Akure, Nigeria \\ ${ }^{2}$ Biochemistry Department, Federal University of Technology, Akure, Nigeria \\ Email: ${ }^{*}$ ciwetan@gmail.com
}

Received 16 May 2015; accepted 27 June 2015; published 30 June 2015

Copyright (C) 2015 by authors and Scientific Research Publishing Inc.

This work is licensed under the Creative Commons Attribution International License (CC BY).

http://creativecommons.org/licenses/by/4.0/

(c) (7)

Open Access

\section{Abstract}

Activity concentrations of twenty-six (26) samples of sediment collected from rivers from eleven (11) oil-producing communities and two (2) non-oil producing communities in Delta state of Nigeria were studied. Hyper Purity Germanium (HPGe) Detector was used for counting and detection of radionuclide content of all samples. Results of the samples analysed showed that the radioactivity concentrations of $\mathrm{K}^{40}, \mathrm{Th}^{232}$ and $\mathrm{U}^{238}$ in the sediment samples from oil-producing areas range from $32.47 \mathrm{~Bq} \cdot \mathrm{kg}^{-1}$ to $525.1 \mathrm{~Bq} \cdot \mathrm{kg}^{-1}$ with an average of $302.15 \mathrm{~Bq} \cdot \mathrm{kg}^{-1}, 6.31 \mathrm{~Bq} \cdot \mathrm{kg}^{-1}$ to 19.33 $\mathrm{Bq} \cdot \mathrm{kg}^{-1}$ with an average of $11.66 \mathrm{~Bq} \cdot \mathrm{kg}^{-1}$, and $4.45 \mathrm{~Bq} \cdot \mathrm{kg}^{-1}$ to $18.69 \mathrm{~Bq} \cdot \mathrm{kg}^{-1}$ with an average of 8.66 $\mathrm{Bq} \cdot \mathrm{kg}^{-1}$ respectively. Activity concentrations at the control site ranged from $3.15 \mathrm{~Bq} \cdot \mathrm{kg}^{-1}$ to 4.80 $\mathrm{Bq} \cdot \mathrm{kg}^{-1}, 2.27 \mathrm{~Bq} \cdot \mathrm{kg}^{-1}$ to $4.18 \mathrm{~Bq} \cdot \mathrm{kg}^{-1}$ and $1.15 \mathrm{~Bq} \cdot \mathrm{kg}^{-1}$ to $1.76 \mathrm{~Bq} \cdot \mathrm{kg}^{-1}$ for $\mathrm{K}^{40}, \mathrm{Th}^{232}$ and $\mathrm{U}^{238}$. These values are within the world average; natural radioactivity mapping of the study area is carried out using the Surfer software. Statistical analysis of the results showed that there is a significant difference between the radionuclide concentrations of the sediment samples from rivers in the oil producing site compared to results from non-oil producing communities, except for one of the oil producing site samples (Idumuesah) which has values that are close to those from the control sites for $\mathrm{K}^{40}$. The values of the radiological assessment indices obtained were observed to be within the permissible maximum values; hence the radiation hazard at study areas are negligible. However, concentration values of studied radionuclide at the oil-producing study areas were observed to be higher than values from the non-oil producing sites in most cases. It could therefore be reported that the operations of the oil companies in Delta state of Nigeria may have contributed to the high radioactivity level of the river sediments. Although the concentration at the time of this study poses no risk, further industrial activities in the study area may raise the activity concentration 
and radiological burden in the future.

Keywords

Sediment, Natural Radioactivity, TENORM, HPGe Detector

\section{Introduction}

Human bodies (muscles, bones, and tissue) contain naturally occurring radioactive elements as man has always been exposed to natural radiation arising from the earth as well as from outside the earth (cosmic rays). The contribution from these components varies with location and altitude [1]. Technologically enhanced naturally occurring radioactive materials (TENORM) are produced when radionuclides that occur naturally in ores, soils, water, or other natural materials are concentrated or exposed to the environment by Industrial activities. Several anthropogenic radionuclides have been detected through national, regional and international monitoring programs designed to periodically assess marine water, sediment and biota [4]. Thus, presence of radioactivity in contaminated environment can be attributed to naturally occurring and artificially induced sources. The mains sources of external $\gamma$-radiation are the radionuclides of the ${ }^{238} \mathrm{U}$ and ${ }^{232} \mathrm{Th}$ series, along with their progeny and ${ }^{40} \mathrm{~K}$. The natural radioactivity of soils and sediments depends on the soil and sediment formation and transport processes that were involved in their formation; chemical and biochemical interactions influence the distribution patterns of uranium, thorium and their decay products [5]. However, naturally occurring radioactive materials present under the ground may, during oil and gas drilling, be enhanced to elevated and harmful levels in "produced waters" and drilling mud from oil and gas extraction equipment [2]. In the recent years, studies on the high background radiation areas in the world have been of prime importance for risk estimation due to long term low-level whole body exposures to the public.

A common feature of many environmental radiation measurement programs is the study of radionuclide distributions and concentrations. In fact, oil producing and other non-nuclear industries may increase the radiation background in the environment due to the higher levels of consumption by these industries of ore materials, which contain radioactive elements. Additionally, the high-temperature burning of these ore materials will increase the release of steam carrying these radioactive elements; such burning is common in the discovery and production of petroleum, coal and phosphate fertilizers and in other heavy industries.

The oil and gas industry is the major user of radioactive sources and the largest producer of radioactive wastes in Nigeria. The uses of radioactive sources in the industry cover both upstream and downstream operations such as well-logging, automated ionizing radiation gauge, radiography and application of radiotracers in oil well management, reservoir studies and leak detection in pipelines [14]. The geologic formations that contain oil and gas deposits also contain naturally-occurring radionuclides and geologists have recognized their presence and use it as a method for finding deposits (Ma87). In the course of oil exploration and production in the study area, various materials such as chlorinated and oil hydrocarbon, heavy metals, artificial radio nuclide, drill cuttings; fluids and drill mud, used for production stimulation are released into water bodies.

The aim of this study was to determine the radioactivity levels due to natural radionuclides of the ${ }^{238} \mathrm{U}$ and ${ }^{232} \mathrm{Th}$ series and ${ }^{40} \mathrm{~K}$ in the river sediment samples that were collected from oil producing communities of Delta states in the Niger Delta region of Nigeria where active exploration and exploitation of petroleum are taking place. Additionally, the average radium equivalent activity (Raeq), the total absorbed dose rate (D), the external hazard index (Hex), the internal hazard index (Hin), the annual gonadal dose equivalent (AGDE) and the annual effective dose equivalent (AEDE) were calculated and compared with results from literatures. The results of this study provide background data on natural radioactive isotopes and environmental contamination due to oil and gas production.

\section{Experimental Procedure}

\subsection{Sampling Technique}

Eleven Oil Producing communities and two non-oil producing communities were identified within Delta state and selected for sampling. Figure 1 shows the map of sampling communities within the state. Sediment samples 


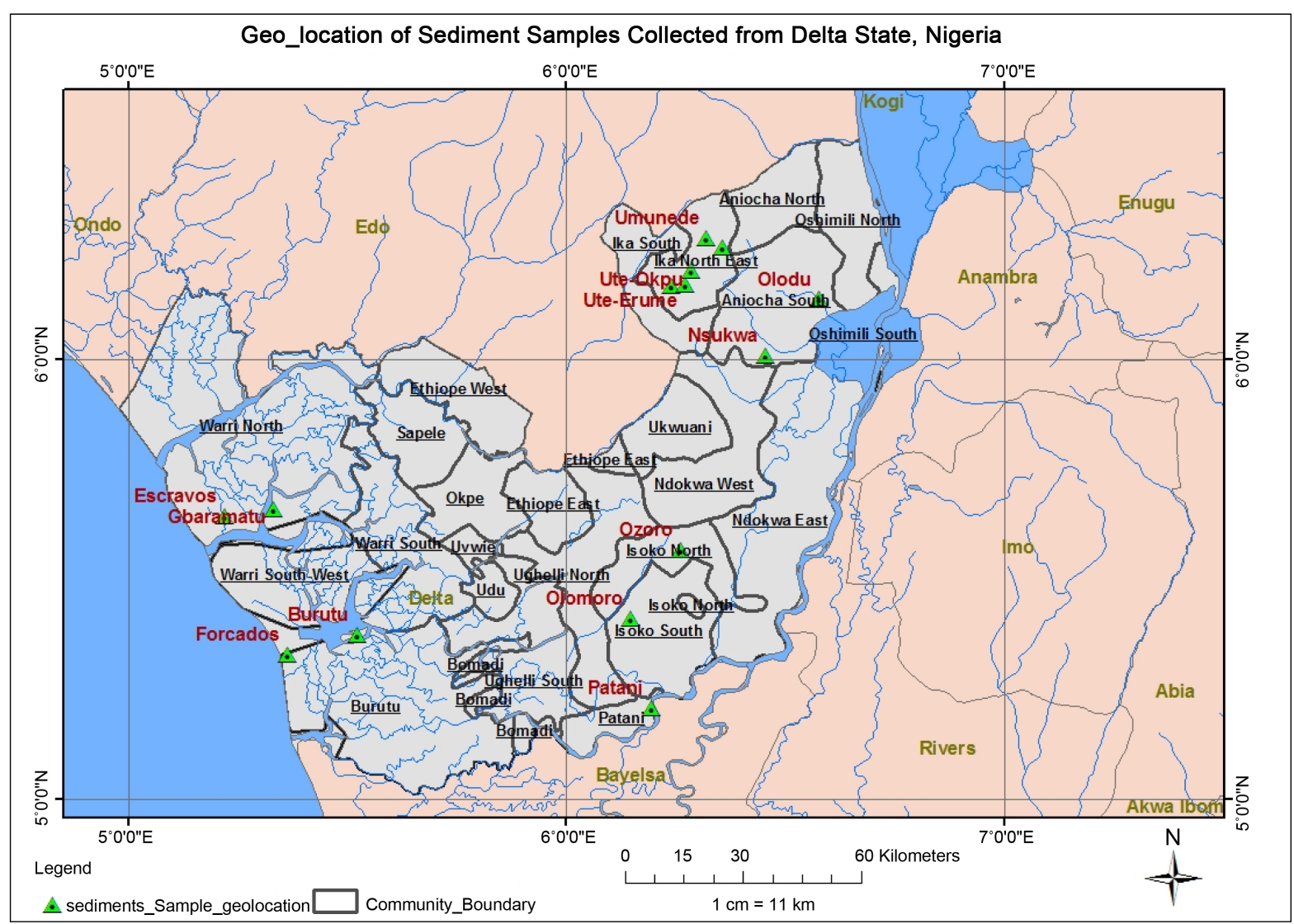

Figure 1. Map of Delta state of Nigeria showing sampling locations.

were collected at approximately $1.2 \mathrm{~km}$ (1) and $800 \mathrm{~m}$ (2) away from visible oil exploration activities within these selected communities. The collected samples were distributed to obtain an average of the concentration of radioactivity for a uniform distribution over the area of interest with samples from the non-oil producing communities as control. The sample collection equipment, containers and sample preparation areas were be kept clean to avoid contamination. Disposable containers (plastic bags, aluminum trays, etc.) were used whenever possible. The box corer; a marine geological sampling tool for soft sediment and suitable for any water depth with minimum disturbance of the sediment surface by bow wave which is important for quantitative investigations, was dropped into the bottom of the river for sediment samples collection.

All samples were collected and prepared according to equipment's specification. Hyper Purity Germanium (HPGe) Detector (Canberra, model gc. 8023) at the National Institute of Radiation Protection and Research, University of Ibadan, Nigeria was used for counting and detection of radionuclide content of sediments samples from all selected locations. Collected samples were transported to the research laboratory on collection days. All samples were allowed to dry at room temperature and pulverised at the laboratory, sieved and put inside two sets of labeled transparent plastic containers. Sediment samples containers were carefully sealed for 4 weeks in order to establish secular radioactive equilibrium between the natural radionuclides and their respective progenies.

\subsection{Instrumentation}

Hyper Purity Germanium (HPGe) Detector was used for counting and detection of radionuclide content of all samples. The instrument have a depleted, sensitive thickness of centimeters, and therefore can be used as a total absorption detector for gamma rays up to few $\mathrm{MeV}$. Cooled to liquid nitrogen temperatures $\left(196^{\circ} \mathrm{C}\right)$, it produces spectroscopic data and pulses proportional to the captured photon energy. The HPGe detector used is a P-type and has a diameter of $78 \mathrm{~mm}$, length $69.6 \mathrm{~mm}, 16 \mathrm{~K}$ channels with relative efficiency of $80 \%$ and a resolution of $2.3 \mathrm{Kev}$ at the ${ }^{60} \mathrm{Co}$ line of $1.33 \mathrm{Mev}$. The spectrometer was equipped with the necessary electronics. A Digital 
Spectrum Analyzer (DSA-1000) was connected to the HPGe, providing the detector with the required voltage and pre amplifier model 2002csl was employed for the pre amplifying stage. Counting time was 28,800 seconds. Multi-gamma ray standard source (mgsAm241) was used for the equipment calibration. Standard point sources gamma emitters (Caesium, Cobalt and Americium) were used for the energy calibration to determine the radionuclide present in the samples within a wide range of photo peaks and efficiency calibration was done using volume source of the same geometry as the samples in determining the activity concentration of the radionuclide present in the samples.

\subsection{Calculation of Activity and Uncertainties}

The efficiency of specific spectrometer is given by the following equation

$$
\eta=\frac{N C}{A \rho_{\gamma} T}
$$

$\eta=$ Efficiency of specific geometry, $N_{c}=$ Net count, $A=$ Activity of standard source.

$\rho_{\gamma}=$ Gamma emission probability or gamma yield and $T=$ Time of Counting (seconds).

An efficiency calibration curve is produced using Excel worksheet, polynomial fittings are performed with a degree that gives the best R2-value that fit very well the two well-known parts of the calibration curves. Two fitting curves were performed separately to reach the maximum agreement with the measured data. With the equations produced from the fitting curves, activity concentration of $\mathrm{U}^{238}, \mathrm{Th}^{232}$ and $\mathrm{K}^{40}\left(\mathrm{~Bq} \cdot \mathrm{kg}^{-1}\right)$ were calculated based on the measured efficiency of the detector and the net count rate as follows:

$$
A=\frac{N_{c}}{\eta \rho_{\gamma} T M}
$$

$M=$ Mass of sample (kg).

Uncertainties in the activity is calculated as given by [13] in Equation (3)

$$
\Delta A=\left[\left(\frac{\Delta C R}{C R}\right)^{2}-(\Delta \eta)^{2}-\left(\Delta \rho_{\gamma}\right)^{2}-(\Delta M)^{2}\right]
$$

where $\Delta A, \Delta N c, \Delta \eta, \Delta \rho_{\gamma}$ and $\Delta M$ are uncertainties in the activity, the count rate, the efficiency, the gamma yield and the mass, respectively.

\section{Results and Discussion}

\subsection{Activity Concentration}

The activities of natural radionuclides $\mathrm{K}^{40}, \mathrm{Th}^{232}$ and $\mathrm{U}^{238}$ in sediment have been analysed in the oil producing communities of Delta states. Table 1 shows the Coordinates of sampling locations, samples ID and activity concentration of the main gamma-emitting natural radionuclides. The Activity values of $\mathrm{K}^{40}$ ranged from 32.47 $\mathrm{Bq} \cdot \mathrm{kg}^{-1}$ to $525.1 \mathrm{~Bq} \cdot \mathrm{kg}^{-1}$ with an average concentration of $302.15 \mathrm{~Bq} \cdot \mathrm{kg}^{-1}$. The values of $\mathrm{Th}^{232}$ ranged from 6.31 $\mathrm{Bq} \cdot \mathrm{kg}^{-1}$ to $19.33 \mathrm{~Bq} \cdot \mathrm{kg}^{-1}$ with an average concentration of $11.66 \mathrm{~Bq} \cdot \mathrm{kg}^{-1}$. The values of $\mathrm{U}^{238}$ ranged from 4.45 $\mathrm{Bq} \cdot \mathrm{kg}^{-1}$ to $18.69 \mathrm{~Bq} \cdot \mathrm{kg}^{-1}$ with an average of $8.66 \mathrm{~Bq} \cdot \mathrm{kg}^{-1}$. Activity concentrations at the control site ranged from 3.15 to $4.80,2.27$ to 4.18 and 1.15 to 1.76 for $\mathrm{K}^{40}, \mathrm{Th}^{232}$ and $\mathrm{U}^{238}$ respectively. Figure 2 which is the radioactivity mapping of study area, shows the level of activity concentration at each sampling location on the map of Delta state. The worldwide concentration of the radionuclide $\mathrm{K}^{40}, \mathrm{Th}^{232}$ and $\mathrm{U}^{238}$ have averages in sediment samples of $40 \mathrm{~Bq} \cdot \mathrm{kg}^{-1}, 40 \mathrm{~Bq} \cdot \mathrm{kg}^{-1}$ and $370 \mathrm{~Bq} \cdot \mathrm{kg}^{-1}$ respectively [19]. Table 2 shows concentrations of the natural radionuclides in sediments samples from different parts of the world compared with those of the present study. The present results demonstrate that the average activity concentrations of these radionuclide are less than the worldwide average concentrations.

\subsection{Absorbed Dose}

Absorbed Dose is calculated by introducing the dose conversion factor for each radionuclide being considered.

$$
\text { Total absorbed dose }=0.043 C_{\mathrm{k}}+0.662 C_{\mathrm{Th}}+0.427 C_{\mathrm{U}}
$$


Table 1. Coordinates of sampling locations, samples ID and activity concentration of the main gamma-emitting natural radionuclides.

\begin{tabular}{|c|c|c|c|c|c|}
\hline Sample ID & Latitude & Longitude & $\mathrm{K}^{40}$ Activity conc. & $\begin{array}{c}T^{232} \\
\text { Activity conc. }\end{array}$ & $\mathrm{U}^{238}$ Activity Conc. \\
\hline ESC-01 & $5^{\circ} 38 ' 39.20^{\prime \prime}$ & $5^{\circ} 13^{\prime} 18.14^{\prime \prime}$ & $390.1 \pm 1.61$ & $6.46 \pm 0.67$ & $5.12 \pm 0.48$ \\
\hline ESC-02 & $5^{\circ} 38 ' 29.13^{\prime \prime}$ & $5^{\circ} 17^{\prime} 03.54^{\prime \prime}$ & $395.2 \pm 1.04$ & $6.71 \pm 0.85$ & $5.49 \pm 0.73$ \\
\hline BRT-01 & $5^{\circ} 22 ' 29.62 "$ & $5^{\circ} 31^{\prime} 19.22^{\prime \prime}$ & $364.3 \pm 1.55$ & $6.31 \pm 1.10$ & $5.90 \pm 0.81$ \\
\hline BRT-02 & $5^{\circ} 20^{\prime} 54.36^{\prime \prime}$ & $5^{\circ} 29^{\prime} 45.10^{\prime \prime}$ & $365.5 \pm 0.57$ & $6.57 \pm 0.72$ & $6.11 \pm 0.41$ \\
\hline FCD-01 & $5^{\circ} 19^{\prime} 41.15^{\prime \prime}$ & $5^{\circ} 21^{\prime} 47.40^{\prime \prime}$ & $248.1 \pm 1.34$ & $7.70 \pm 0.88$ & $9.91 \pm 1.33$ \\
\hline FCD-02 & $5^{\circ} 20^{\prime} 41.15^{\prime \prime}$ & $5^{\circ} 17^{\prime} 03.49^{\prime \prime}$ & $261.4 \pm 1.02$ & $8.57 \pm 0.62$ & $9.96 \pm 1.17$ \\
\hline OZO-01 & $556 ' 8553$ & 6.241788 & $457.9 \pm 1.96$ & $14.50 \pm 1.68$ & $9.75 \pm 1.11$ \\
\hline OZO-02 & $5.56 ' 6116$ & 6.2619715 & $459.2 \pm 1.32$ & $14.81 \pm 0.85$ & $9.92 \pm 0.72$ \\
\hline OLM-01 & $5.41 ' 1309$ & 6.148099 & $522.4 \pm 2.28$ & $18.78 \pm 2.44$ & $18.63 \pm 1.81$ \\
\hline OLM-02 & $5.41 ' 876$ & 6.16947 & $525.1 \pm 1.17$ & $19.33 \pm 1.69$ & $18.69 \pm 1.13$ \\
\hline GBA-01 & $5^{\circ} 40^{\prime} 43.59^{\prime \prime}$ & $5^{\circ} 22 ' 35.12^{\prime \prime}$ & $470.8 \pm 2.02$ & $9.46 \pm 1.10$ & $6.76 \pm 0.67$ \\
\hline GBA-02 & $5^{\circ} 39 ' 21.48 "$ & $5^{\circ} 10^{\prime \prime} 06.65 "$ & $476.6 \pm 2.13$ & $9.77 \pm 1.51$ & $6.78 \pm 0.49$ \\
\hline UMD-01 & $6^{\circ} 27^{\prime} 2976$ & 6.302832 & $319.1 \pm 1.43$ & $8.86 \pm 0.75$ & $5.50 \pm 0.58$ \\
\hline UMD-02 & $6^{\circ} 27^{\prime} 498$ & 6.321213 & $319.8 \pm 0.38$ & $9.25 \pm 0.92$ & $5.61 \pm 0.36$ \\
\hline OLD-01 & $6^{\circ} 13^{\prime} 7199$ & 6.578300 & $170.0 \pm 1.11$ & $11.43 \pm 1.84$ & $7.32 \pm 0.59$ \\
\hline OLD-02 & $6^{\circ} 12 " 5453$ & 6.488750 & $172.4 \pm 0.94$ & $11.46 \pm 1.34$ & $7.71 \pm 0.73$ \\
\hline PAT-01 & $5^{\circ} 16^{\prime} 56.10^{\prime \prime}$ & $6^{\circ} 03^{\prime} 36.03^{\prime \prime}$ & $264.2 \pm 1.43$ & $16.13 \pm 1.72$ & $12.25 \pm 1.50$ \\
\hline PAT-02 & $5^{\circ} 13^{\prime} 06.09 "$ & $6^{\circ} 07^{\prime} 04.21^{\prime \prime}$ & $264.9 \pm 1.15$ & $16.64 \pm 1.22$ & $12.29 \pm 1.14$ \\
\hline NSK-01 & $6^{\circ} 00^{\prime} 91.86$ & $6.45^{\prime} 5.45$ & $63.8 \pm 0.58$ & $15.47 \pm 1.94$ & $8.65 \pm 1.04$ \\
\hline NSK-02 & $6^{\circ} 00^{\prime} 8.77$ & $6.49^{\prime} 0.06$ & $68.1 \pm 0.45$ & $15.55 \pm 1.18$ & $8.69 \pm 0.62$ \\
\hline IDU-01 & $6^{\circ} 10^{\prime} 01.43^{\prime \prime}$ & $6^{\circ} 14^{\prime} 22.42^{\prime \prime}$ & $32.47 \pm 0.67$ & $10.90 \pm 1.16$ & $4.45 \pm 0.54$ \\
\hline IDU-02 & $6^{\circ} 10^{\prime} 14.64 "$ & $6^{\circ} 18^{\prime} 17.09 "$ & $35.92 \pm 0.59$ & $11.83 \pm 1.09$ & $4.91 \pm 0.37$ \\
\hline OGH-1 & $5^{\circ} 10^{\prime} 18.50^{\prime \prime}$ & $6^{\circ} 11^{\prime} 4439^{\prime \prime}$ & $4.63 \pm 1.09$ & $2.27 \pm 0.82$ & $1.31 \pm 0.55$ \\
\hline OGH-2 & $5^{\circ} 13^{\prime} 11.19^{\prime \prime}$ & $6^{\circ} 10^{\prime} 2642 "$ & $4.80 \pm 1.13$ & $2.54 \pm 0.98$ & $1.76 \pm 0.74$ \\
\hline SAP-1 & 550'28.33" & 54'19.63" & $3.15 \pm 0.79$ & $3.92 \pm 1.16$ & $1.15 \pm 0.59$ \\
\hline SAP-2 & 550'31.45" & $5^{\circ} 4^{\prime} 411.77^{\prime \prime}$ & $3.38 \pm 0.95$ & $4.18 \pm 1.81$ & $1.49 \pm 0.87$ \\
\hline
\end{tabular}

Table 2. Concentrations of the natural radionuclides in sediments samples from different parts of the world compared with those of the present.

\begin{tabular}{|c|c|c|c|c|c|}
\hline \multirow[t]{2}{*}{ Country } & \multicolumn{3}{|c|}{ Activity Concentration Bq/kg } & \multirow[t]{2}{*}{ Description } & \multirow[t]{2}{*}{ Reference } \\
\hline & K40 & Th232 & $\mathrm{U} 238$ & & \\
\hline World Average & 370.00 & 40.00 & 40.00 & & {$[19]$} \\
\hline Italy & 442.50 & 32.00 & 56.00 & Albano Terme & [7] \\
\hline Albania & 470.50 & 26.50 & 17.5 & Butrint Lagoon & {$[18]$} \\
\hline Turkey & 537.00 & 38.00 & 39.00 & Fatina Valley & {$[11]$} \\
\hline India & 384.03 & 46.8 & 70.31 & Ponnaiyar River & {$[16]$} \\
\hline Serbia & 445.00 & 36.00 & 42.00 & Danube River & {$[10]$} \\
\hline Chana & 379.94 & 6.91 & 7.31 & Tono Irrigation Dam & {$[17]$} \\
\hline Saudi Arabia & 416.57 & 5.90 & 11.17 & Jeddah Land Runway & {$[13]$} \\
\hline Nigeria & 302.15 & 11.66 & 8.66 & Delta State Rivers & Present Study \\
\hline
\end{tabular}


$\mathrm{K}^{40}$ Activity concentration
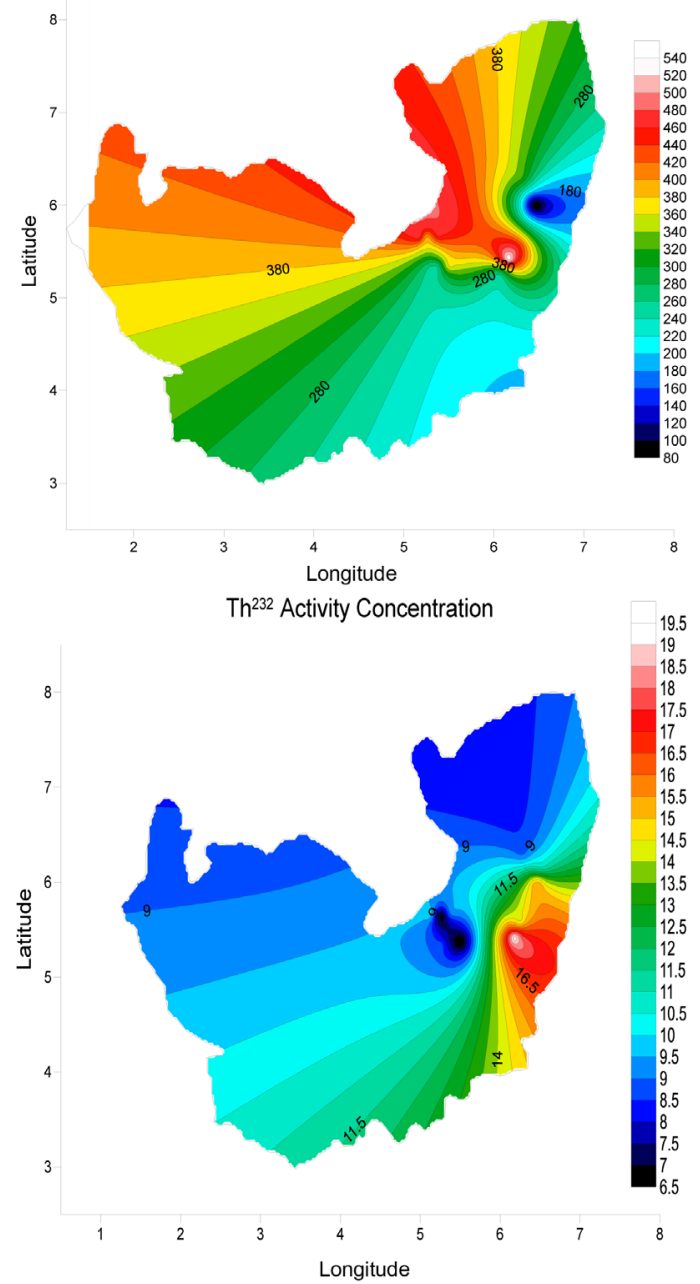

$\mathrm{U}^{238}$ Activity Concentration

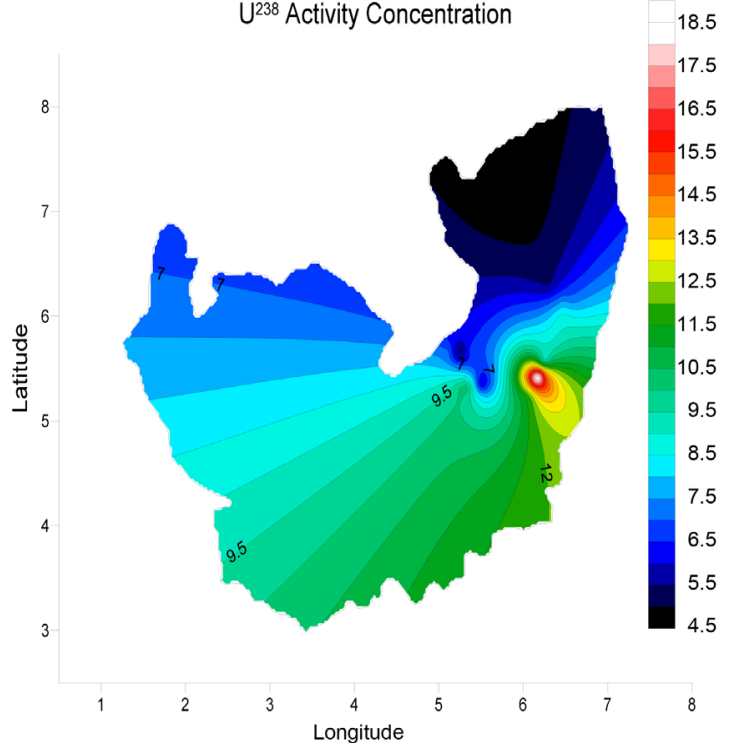

Figure 2. Map of Delta state showing the radioactivity mapping for $\mathrm{K}^{40}, \mathrm{Th}^{232}$ and $\mathrm{U}^{238}$ in sediment samples. 
where $C_{\mathrm{K}}, C_{\mathrm{Th}}$ and $C_{\mathrm{U}}$ are activity concentration of $\mathrm{K}^{40}, \mathrm{Th}^{223}$ and $\mathrm{U}^{238}$ respectively. Table 3 shows range of activity concentrations, mean concentration, Absorbed Dose and Annual Effective dose equivalent of $K^{40}, \mathrm{Th}^{232}$ and $\mathrm{U}^{238}$ in the sediment samples. Figure 3 shows the variation in the total absorbed dose in sediment samples across sample locations in Delta state.

\subsection{Radium Equivalent Dose ( $\left.R a_{\text {eq }}\right)$}

A common index used to compare the specific activities of materials containing $\mathrm{U}^{238}, \mathrm{Th}^{232}$ and $\mathrm{K}^{40}$ by a single quantity, also takes into account the radiation hazards associated with them [3] [6]. The radium equivalent is related to both the external $\gamma$-dose and the internal $\alpha$-dose from radon and its progeny. The activity index provides a useful guideline in regulating the safety standards. The radium equivalent activity index is calculated as given by [5] in Equation (5).

$$
R a_{e q}=C_{\mathrm{Ra}}+1.43 C_{\mathrm{Th}}+0.077 C_{\mathrm{K}}
$$

where; $C_{\mathrm{Ra}}, C_{\mathrm{Th}}$ and $C_{\mathrm{K}}$, are the radioactivity concentration in $\mathrm{Bq} \cdot \mathrm{kg}^{-1}$ of ${ }^{238} \mathrm{U},{ }^{232} \mathrm{Th}$ and ${ }^{40} \mathrm{~K}$ respectively.

The above equation is based on the assumption that $370 \mathrm{~Bq} \cdot \mathrm{kg}^{-1}$ of ${ }^{226} \mathrm{Ra}, 259 \mathrm{~Bq} \cdot \mathrm{kg}^{-1}$ of ${ }^{232} \mathrm{Th}$, and 4810 $\mathrm{Bq} \cdot \mathrm{kg}^{-1}$ of ${ }^{40} \mathrm{~K}$ produce the same gamma-ray dose rate. The values of the Radium Equivalent doses are given in Table 4 and ranged from $13.48 \mathrm{~Bq} \cdot \mathrm{kg}^{-1}$ to $52.86 \mathrm{~Bq} \cdot \mathrm{kg}^{-1}$ at sampling location with known anthropogenic input (oil exploration) and ranged from $5.19 \mathrm{~Bq} \cdot \mathrm{kg}^{-1}$ to $5.70 \mathrm{~Bq} \cdot \mathrm{kg}^{-1}$ at the control sites. The permissible maximum value of the radium equivalent activity is $370 \mathrm{~Bq} \cdot \mathrm{kg}^{-1}$, which corresponds to an effective dose of $1 \mathrm{mSv} \cdot \mathrm{yr}^{-1}$ for to the inhabitants of dwellings [19].

\subsection{Annual Gonadal Dose Equivalent (AGDE)}

The gonads, the bone marrow and the bone surface cells are considered as organs of interest by [19]. The AGDE for given activity concentration of $\mathrm{U}^{238}, \mathrm{Th}^{232}$ and $\mathrm{K}^{40}$ is calculated using the Equation (6)

$$
\operatorname{AGDE}(\mu \mathrm{Sv} / \mathrm{yr})=3.09 C_{\mathrm{Ra}}+4.18 C_{\mathrm{Th}}+0.314 C_{\mathrm{K}}
$$

where $C_{\mathrm{Ra}}, C_{\mathrm{Th}}$ and $C_{\mathrm{K}}$ are the radioactivity concentration of $\mathrm{U}^{238} \mathrm{Th}^{232}$ and $\mathrm{K}^{40}$.

Values of AGDE as shown in Table 4 ranged from $66.54 \mathrm{mSv} \cdot \mathrm{yr}^{-1}$ to $207.5 \mathrm{mSv} \cdot \mathrm{yr}^{-1}$ with an average of 137.02 in study areas with visible anthropogenic input and 20.8 to 25.39 with an average of 23.09 at the control sites. The standard UNSCEAR value for AGED is $300 \mathrm{mSv} \cdot \mathrm{yr}^{-1}$.

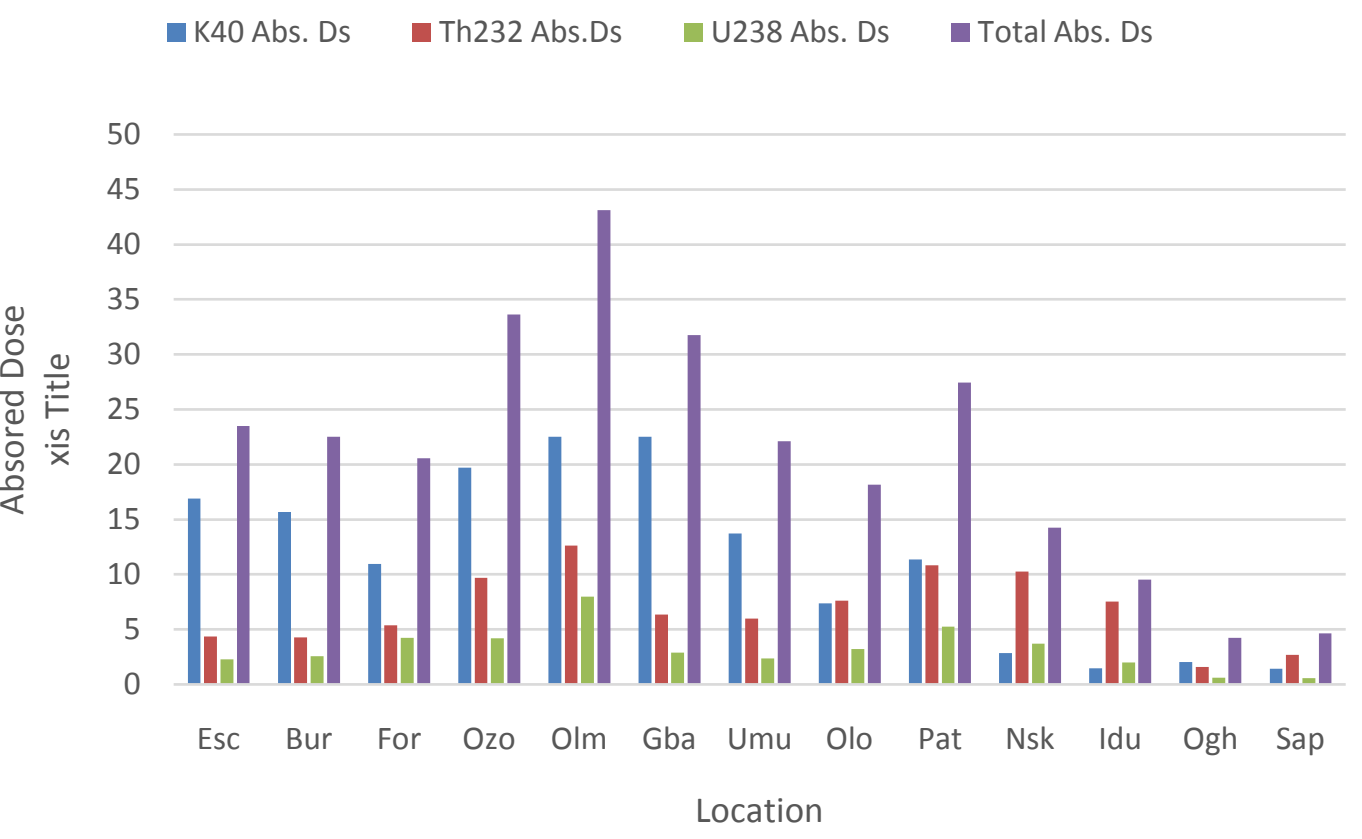

Figure 3. Variation in the total absorbed dose in sediment samples across sample locations in Delta state. 
Table 3. Range of activity concentration, mean concentration absorbed dose and annual effective equivalent dose of $\mathrm{K}^{40}$ $\mathrm{Th}^{232}$ and $\mathrm{U}^{238}$ in sediment samples collected from locations in the oil producing communities of Delta state, Nigeria.

\begin{tabular}{|c|c|c|c|c|c|c|c|c|}
\hline Site & $\begin{array}{c}\mathbf{K}^{40} \\
\text { Activity } \\
\text { Range } \\
\left(\mathbf{B q} \cdot \mathbf{k g}^{-1}\right)\end{array}$ & $\begin{array}{c}\mathrm{K}^{40} \text { Mean } \\
\text { Activity } \\
\left(\mathrm{Bq} \cdot \mathrm{kg}^{-1}\right)\end{array}$ & $\begin{array}{c}\mathrm{Th}^{232} \\
\text { Activity } \\
\text { Range } \\
\left(\mathbf{B q} \cdot \mathbf{k g}^{-1}\right)\end{array}$ & $\begin{array}{c}\mathrm{Th}^{232} \\
\text { Mean } \\
\text { Activity } \\
\left(\mathbf{B q} \cdot \mathrm{kg}^{-1}\right)\end{array}$ & $\begin{array}{c}\mathbf{U}^{238} \\
\text { Activity } \\
\text { Range } \\
\left(\mathbf{B q} \cdot \mathbf{k g}^{-1}\right)\end{array}$ & $\begin{array}{c}\mathrm{U}^{238} \text { Mean } \\
\text { Activity } \\
\left(\mathrm{Bq} \cdot \mathrm{kg}^{-1}\right)\end{array}$ & $\begin{array}{l}\text { Abs Dose } \\
\left(\mathbf{n G y} \cdot h^{-1}\right)\end{array}$ & $\underset{\left(\mu \mathrm{Sv} \cdot \mathbf{y r}^{-1}\right)}{\text { AEDE }}$ \\
\hline Esc & 390.1 - 395.2 & 392.65 & $6.46-6.71$ & 6.585 & $5.12-5.49$ & 5.305 & 23.509 & 28.831 \\
\hline Bur & $364.3-365.5$ & 364.9 & $6.31-6.57$ & 6.44 & $5.9-6.11$ & 6.005 & 22.518 & 27.616 \\
\hline For & $248.1-261.4$ & 254.75 & $7.7-8.57$ & 8.135 & $9.91-9.96$ & 9.935 & 20.582 & 25.242 \\
\hline Ozo & $45.79-459.2$ & 458.55 & 14.5 - 14.81 & 14.655 & 9.75 - 9.92 & 9.835 & 33.619 & 41.230 \\
\hline Olm & $52.24-525.1$ & 523.75 & $18.78-19.33$ & 19.055 & 18.63 - 18.69 & 18.66 & 43.104 & 52.862 \\
\hline Gba & 47.08 - 476.6 & 523.7 & $9.46-9.77$ & 9.615 & $6.76-6.78$ & 6.77 & 31.775 & 38.969 \\
\hline Umu & 31.91 - 319.8 & 319.45 & $8.86-9.25$ & 9.055 & $5.50-5.61$ & 5.555 & 22.103 & 27.107 \\
\hline Olo & $170.0-172.4$ & 171.2 & $11.43-11.56$ & 11.495 & $7.31-7.71$ & 7.51 & 18.178 & 22.294 \\
\hline Pat & $264.2-264.9$ & 264.55 & $16.13-16.64$ & 16.385 & $12.25-12.29$ & 12.27 & 27.461 & 33.679 \\
\hline Nsk & $63.80-68.11$ & 65.95 & $15.47-15.55$ & 15.51 & $8.65-8.69$ & 8.67 & 16.806 & 20.610 \\
\hline Idu & $32.47-35.92$ & 34.19 & 10.9 - 11.83 & 11.365 & $4.45-4.91$ & 4.68 & 10.992 & 13.481 \\
\hline Ogh & $46.20-48.10$ & 47.1 & $2.27-2.54$ & 2.41 & $1.31-1.55$ & 1.43 & 4.231 & 5.189 \\
\hline Sap & $31.50-33.81$ & 32.7 & $3.92-4.18$ & 4.05 & $1.15-1.49$ & 1.32 & 4.651 & 5.704 \\
\hline
\end{tabular}

Table 4. Activity concentrations of $\mathrm{K}^{40}, \mathrm{Th}^{232}$ and $\mathrm{U}^{238}$, Radium Equivalent Dose (Req), annual gonadal equivalent dose (AGED), external hazard index $\left(\mathrm{H}_{\mathrm{ex}}\right)$ and internal hazard index $\left(\mathrm{H}_{\mathrm{in}}\right)$ of NORM in sediment samples from the study area.

\begin{tabular}{|c|c|c|c|c|c|c|c|}
\hline Location & $\begin{array}{c}\mathrm{K}^{40} \text { Activity } \\
\mathrm{Bq} \cdot \mathrm{kg}^{-1}\end{array}$ & $\begin{array}{c}\mathrm{Th}^{232} \\
\text { Activity } \\
\mathrm{Bq} \cdot \mathrm{kg}^{-1}\end{array}$ & $\begin{array}{c}\mathbf{U}^{238} \\
\text { Activity } \\
\mathbf{B q} \cdot \mathbf{k g}^{-1}\end{array}$ & Req Bq $\cdot \mathbf{k g}^{-1}$ & $\begin{array}{c}\text { AGED } \\
\mu \mathrm{Sv} \cdot \mathbf{y r}^{-1}\end{array}$ & Hex & Hin \\
\hline Esc & 392.65 & 6.585 & 5.305 & 44.956 & 96.53285 & 0.121395 & 0.135732 \\
\hline Bur & 364.9 & 6.44 & 6.005 & 43.312 & 94.37125 & 0.116957 & 0.133187 \\
\hline For & 254.75 & 8.135 & 9.935 & 41.184 & 98.83995 & 0.111223 & 0.138075 \\
\hline Ozo & 458.55 & 14.655 & 9.835 & 66.101 & 153.09375 & 0.178497 & 0.205078 \\
\hline Olm & 523.75 & 19.055 & 18.66 & 86.237 & 207.4918 & 0.232892 & 0.283324 \\
\hline Gba & 523.7 & 9.615 & 6.77 & 60.844 & 131.2858 & 0.164298 & 0.182595 \\
\hline Umu & 319.45 & 9.055 & 5.555 & 43.101 & 97.82115 & 0.116389 & 0.131402 \\
\hline Olo & 171.2 & 11.495 & 7.51 & 37.130 & 94.1958 & 0.100272 & 0.120569 \\
\hline Pat & 264.55 & 16.385 & 12.27 & 56.071 & 141.8533 & 0.151425 & 0.184587 \\
\hline Nsk & 65.95 & 15.51 & 8.67 & 35.928 & 100.4594 & 0.097028 & 0.12046 \\
\hline Idu & 34.19 & 11.365 & 4.68 & 23.565 & 66.54836 & 0.063637 & 0.076286 \\
\hline Ogh & 47.1 & 2.41 & 1.43 & 8.503 & 20.8039 & 0.022962 & 0.026827 \\
\hline Sap & 32.7 & 4.05 & 1.32 & 9.629 & 25.3896 & 0.026003 & 0.029571 \\
\hline
\end{tabular}

\subsection{External Hazard Index $\left(H_{\mathrm{Ex}}\right)$ External Hazard Index $\left(H_{\mathrm{ex}}\right)$}

The external hazard index, a relation that quantifies the exposure factor [8] is an evaluation of the hazard of the natural gamma radiation and given by [12] in Equation (7)

$$
H_{\mathrm{ex}}=\frac{C_{\mathrm{K}}}{4810}+\frac{C_{\mathrm{Th}}}{259}+\frac{C_{\mathrm{Ra}}}{370}
$$


where $C_{\mathrm{Ra}}=C_{\mathrm{U}}, C_{\mathrm{Th}}$ and $C_{\mathrm{K}}$ are the activity concentrations of ${ }^{238} \mathrm{U},{ }^{226} \mathrm{Ra},{ }^{232} \mathrm{Th}$ and ${ }^{40} \mathrm{~K}$, respectively, in $\mathrm{Bq} / \mathrm{kg}$. Table 4 show that the values of $H_{\text {ex }}$ ranged from 0.023 to 0.23 in all study locations which is less than 1 . Hence, the radiation hazard at study areas are negligible. Figure 4 shows the variation of some radiological indices

\subsection{Internal Hazard Index $\boldsymbol{H}_{\text {in }}$}

In addition to external hazard index, radon and its short-lived products are also hazardous to the respiratory organs. The internal exposure to radon and its daughter products is quantified by the internal hazard index $\mathrm{H}_{\mathrm{in}}$, as given by [20] in Equation (8)

$$
H_{\text {in }}=\frac{C_{\mathrm{K}}}{4810}+\frac{C_{\mathrm{Th}}}{259}+\frac{C_{\mathrm{Ra}}}{185}
$$

where $C_{\mathrm{Ra}}=C_{\mathrm{U}}, C_{\mathrm{Th}}$ and $C_{\mathrm{K}}$ are the activity concentrations of ${ }^{238} \mathrm{U},{ }^{226} \mathrm{Ra},{ }^{232} \mathrm{Th}$ and ${ }^{40} \mathrm{~K}$, respectively, in $\mathrm{Bq} / \mathrm{kg}$. Values of $H_{\text {in }}$ ranged from 0.027 to 0.28 in all study locations. The values of $H_{\text {in }}$ is less than unity hence the radiation hazard is negligible.

\subsection{Annual Effective Dose Equivalent (AEDE)}

In estimating the annual effective dose equivalents, the conversion coefficient from the absorbed dose inairand the outdoor occupancy factor were considered. A value of $0.7 \mathrm{~Sv} / \mathrm{Gy}$ was used for the conversion coefficient from the absorbed dose in air to an effective dose received by adults and 0.2 for the outdoor occupancy factor (UNSCEAR 2000). The annual effective dose equivalent was calculated from equation

$$
\operatorname{AEDE}(\mu \mathrm{Sv} / \mathrm{yr})=D\left(\mathrm{nGy} \cdot \mathrm{h}^{-1}\right) \times 8760 \mathrm{~h} \cdot \mathrm{y}^{-1} \times 0.2 \times 0.7 \mathrm{~Sv} \cdot \mathrm{Gy}^{-1} \times 10^{-3}
$$

The values of the calculations are given in Table 3 . The annual effective dose rate values in the sites with known anthropogenic input as shown in Table 4 varied from $13.48 \mu \mathrm{Sv} / \mathrm{y}$ to $52.86 \mu \mathrm{Sv} / \mathrm{y}$ while those from the control sites varied from $5.19 \mu \mathrm{Sv} / \mathrm{y}$ to $5.70 \mu \mathrm{Sv} / \mathrm{y}$. The world average annual effective dose equivalent (AEDE) from outdoor UNSCEAR (2000) $70 \mu \mathrm{Sv} / \mathrm{y}$. Therefore, with the obtained value slower than the world average value they pose no risk to the environment.

The average AEDE value was calculated as $69.8 \mu \mathrm{Sv} / \mathrm{y}$ in Istanbul (Turkey) [9], $152 \mu \mathrm{Sv} / \mathrm{y}$ in the Xiazhuang Granite Area China) [21], 314.1 $\mu \mathrm{Sv} / \mathrm{y}$ in the Southeast part of Eskisehir (Turkey) [15], and). These average values are generally higher than the present value.

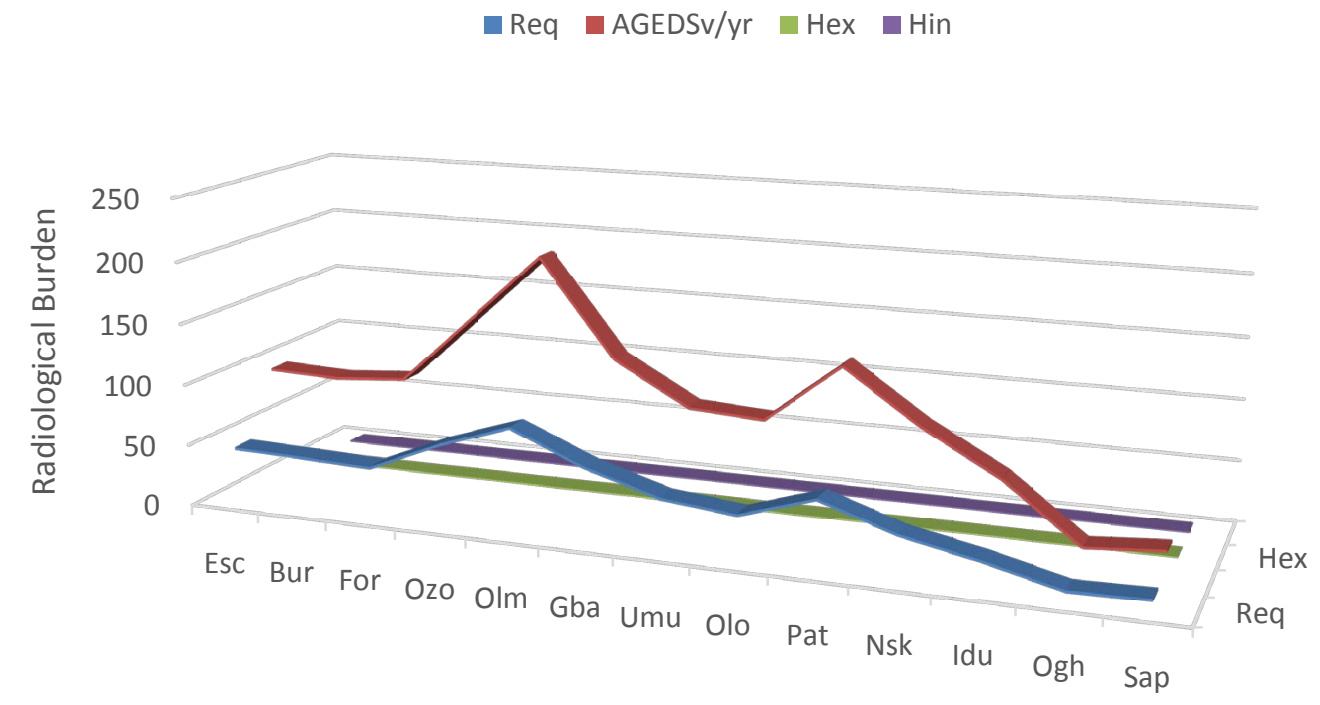

Location

Figure 4. Variation of radium equivalent dose, annual gonadal equivalent dose, external hazard index and internal hazard index in sediment samples. 


\subsection{Natural Radioactivity Mapping}

Radioactivity mapping of the study area was carried out using the Surfer programming software. Surfer is a contouring and 3D surface mapping program that runs under Microsoft Windows. The program was used to converts data generated for activity concentration at different coordinates of location within the state into maps. Figure 2 shows the radioactivity mapping of study sites within Delta state for $\mathrm{K}^{40}$, $\mathrm{Th}^{232}$ and $\mathrm{U}^{238}$ in sampled sediments.

\section{Conclusion}

The natural radioactivity concentrations of a total of twenty-six (26) samples of sediment collected from rivers from eleven (11) oil-producing communities and two communities with no oil and gas industry in Delta state of Nigeria have been determined. Statistical analysis of the results showed that there is significant difference between the radionuclide concentration of the sediment samples from most of the rivers in the oil producing study area compared with results from the non-oil producing sites except for one of the oil producing site sample (Idumuesah) which has values that are close to those from the control sites for $\mathrm{K}^{40}$. Results from this study show that the average activity concentrations of the natural radionuclide considered are less than the worldwide average concentrations. The values of these natural radionuclide concentrations however translate to the determination of the radiological impact assessment values. The values of the radiological assessment indices obtained were observed to be lower than limits internationally reported and fall within the permissible maximum values, hence the radiation hazard at study areas are negligible. However, it was observed that concentration values of naturally occurring radioactive at the oil-producing study areas are in most cases higher than values from the non-oil producing sites. It could therefore be reported that the operations of the oil companies in Delta state of Nigeria which involve the use of radioactive materials may have contributed to the high radioactivity level of the river sediments, thus, the observed radionuclide could be classified as TENORM. Although the concentration at the time of this study pose no risk, further industrial activities in the study area may raise the activity concentrations and radiological burden, which may generate radiation exposure levels that will require attention in the future. Ingestion and inhalation of uranium and thorium and their decay products are of great concern because of the documented medical carcinogenic causes and effects to human. No artificial radionuclide is observed in the samples analysed, the results presented in this work may thus be used as a baseline for future investigations. It is necessary to determine the radioactivity concentrations in the sediments of other parts of the Niger-Delta region of Nigeria. The results may also be used as a reference data for monitoring possible future radioactivity pollution in the study area.

\section{References}

[1] Ajayi, O.S. (2002) Evaluation of Absorbed Dose Rate and Annual Effective Dose Equivalent Due to Terrestrial Gamma Radiation in Rocks in a Part of Southwestern Nigeria. Radiation Protection Dosimetry, 98, 441. http://dx.doi.org/10.1093/oxfordjournals.rpd.a006736

[2] Paschoa, A.S. and Steinhausler, F., Eds. (2010) Technologically Enhanced Natural Radiation. Elsevier Publications, Oxford.

[3] Gregory, A., Emmanuel, E. and Ezekiel, A. (2013) Gamma Spectroscopy Analysis of Produced Water from Selected Flow Stations in Delta State, Nigeria. International Journal of Environmental Monitoring and Analysis, 1, 167-174. http://dx.doi.org/10.11648/j.ijema.20130105.11

[4] Friedlander, B., et al. (2005) Radionuclide in the Marine Environment, A CRESP Science Review, Consortium for Risk Evaluation with Stakeholder Participation.

[5] Beretka, J. and Matthew, P.J. (1985) Natural Radioactivity of Australian Building Materials, Industrial Wastes and By-Products. Health Physics, 48, 87. http://dx.doi.org/10.1097/00004032-198501000-00007

[6] Diab, H.M., Nouh, S.A., Hamdy, A. and El-Fiki, S.A. (2008) Evaluation of Natural Radioactivity in a Cultivated Area around a Fertilizer Factory. Journal of Nuclear and Radiation Physics, 3, 53-62.

[7] Doretti, L., Ferrar, D., Barison, G., Gerbasi, R. and Battiston, G. (1992) Natural Radionuclides in the Mud Sand Waters Used in Thermal Therapy in Abano Terme. Italy. Radiation Protection Dosimetry, 45, 175-178.

[8] Girigisu, S., Ibeanu, I.G.E., Adeyemo, D.J., Onoja, R.A., Bappah, I.A. and Okoh, S. (2013) Scholars Research Library Journal Archives of Applied Science Research, 5, 204-210.

[9] Karahan, G. and Bayulken, A. (2000) Assessment of Gamma Dose Rates around Istanbul, Turkey. Journal of Envi- 
ronmental Radioactivity, 47, 213-221. http://dx.doi.org/10.1016/S0265-931X(99)00034-X

[10] Krmar, M., Slivka, J., Varga, E., Bikit, I. and Vesković, M. (2009) Correlations of Natural Radionuclides in Sediment from Danube. Journal of Geochemical Exploration, 100, 20-24. http://dx.doi.org/10.1016/j.gexplo.2008.03.002

[11] Kurnaz, A., Küçükömeroğlu, B., Keser, R., Okumusoglu, N.T., Korkmaz, F., Karahan, G. and Çevik, U. (2007) Determination of Radioactivity Levels and Hazards of Soil and Sediment Samples in Firtına Valley (Rize, Turkey). Applied Radiation and Isotopes, 65, 1281-1289. http://dx.doi.org/10.1016/j.apradiso.2007.06.001

[12] Mujahid, S.A., Rahim, A., Hussain, S. and Farooq, M. (2008) Measurements of Natural Radioactivity and Radon Exhalation Rates from Different Brands of Cement Used in Pakistan. Radiation Protection Dosimetry, 130, $206-212$. http://dx.doi.org/10.1093/rpd/ncm497

[13] Mohery, M., Baz, S., Lelany, A.M. and Abdallah, A.M. (2014) Environmental Radiation Levels in Soil and Sediments Samples Collected from Floating Water from a Land Runway Resulting from Heavy Rains in the Jeddah Region, KSA. Journal of Radiation Physics and Chemistry, 97, 16-24. http://dx.doi.org/10.1016/j.radphyschem.2013.10.007

[14] Oni, O.M., Farai, I.P. and Awodugba, A.O. (2011) Natural Radionuclide Concentrations and Radiological Impact Assessment of River Sediments of the Coastal Areas of Nigeria. Journal of Environmental Protection, 2, 418-423. http://dx.doi.org/10.4236/jep.2011.24047

[15] Orgunetal, Y., Altınsoy, N., Gultekin, A.H., Karahan, G. and Celebi, N. (2005) Natural Radioactivity Levels in Granitic Plutons and Groundwaters in Southeast Part of Eskisehir, Turkey. Applied Radiation and Isotopes, 63, 267-275. http://dx.doi.org/10.1016/j.apradiso.2005.03.008

[16] Ramasamy, V., Suresh, G., Rajkumar, P., Murugesan, S., Mullainathan, S. and Meenakshisundaram, V. (2011) Reassessment and Comparison of Natural Radioactivity Levels in Relation to Granulometric Contents of Recently Excavated Major River Sediments. Journal of Radioanalytical and Nuclear Chemistry, 292, 381-393. http://dx.doi.org/10.1007/s10967-011-1486-z

[17] Agalga, R., Darko, E.O. and Schandof, C. (2013) Preliminary Study on the Levels of Natural Radionuclides in Sediments of the Tono Irrigation Dam, Navrongo. International Journal of Science and Technology, 2, 770-776.

[18] Tsabaris, C., Eleftheriou, G., Kapsimalis, V., Anagnostou, C., Vlastou, R., Durmishi, C., Kedhi, M. and Kalfas, C.A. (2007) Radioactivity Levels of Recent Sediments in the Butrint Lagoon and the Adjacent Coast of Albania. Applied Radiation and Isotopes, 65, 445-453. http://dx.doi.org/10.1016/j.apradiso.2006.11.006

[19] UNSCEAR (2000) Sources and Effects of Ionizing Radiation. United Nations Scientific Committee on the Effects of Atomic Radiation, United Nations Publication, New York.

[20] Lu, X.W. (2004) Natural Radioactivity in Some Building Materials and By-Products of Shaanxi, China. Journal of Radioanalytical and Nuclear Chemistry, 262, 775-777. http://dx.doi.org/10.1007/s10967-004-0509-4

[21] Yang, Y.X., Wu, X.M., Jiang, Z.Y., Wang, W.X., Lu, J.G., Lin, J., Wang, L.M. and Hsia, Y.F. (2005) Radioactivity Concentrations in Soils of the Xiazhuang Granite Area, China. Applied Radiation and Isotopes, 63, 255-259. http://dx.doi.org/10.1016/j.apradiso.2005.02.011 